\section{THE FOREST RESEARCH INSTITUTE, DEHRA DUN}

IN a Dispatch of the Governor-General in Council, India (dated Nov. 1, 1862), which merits a closer study than some parts of the Empire and Commonwealth appear to have given it, the formation of an Indian Forest Service with an inspector-general of forests at its head as adviser to the GovernorGeneral was advocated, in order to check the excessive exploitment and waste of the forests of that country, which had been greatly intensified with the increased demand following the establishment of ordered rule, and to reserve and conserve selected forest areas. In sanctioning the proposals, the Secretary of State for India wrote that whereas capital expenditure might and would be justifiably spent in ameliorating ruined forests and in opening out inaccessible ones, he was assured that the work projected would result in, a valuable forest estate accruing, which in due course, in addition to being of the greatest benefit to the people, would bring in an increasing revenue to the Government. This inspired prophecy was abundantly fulfilled.

Yet, something more than half a century later, so incalculable is the potential value of the great forest estate in India, that the Government of India wrote (to the Secretary of State), "the greater part of our Forest properties are undeveloped". The subject then in question was research and the Forest Research Institute at Dehra Dun. This was inaugurated in 1906, a research building erected and opened in 1912 and soon after came the War of 1914-18. Imports of many material products in common use in India came to an end, and the young Research Institute was called upon to investigate the possibility of replacing them with raw materials from the forests. The success achieved is common history. The second Dispatch, from which the above sentence is quoted, proceeds to point out that the existing research buildings were totally inadequate to the demands of the Institute and proposed, in addition to considerable increases of the research staff, the purchase of a site of 1,200 acres and the erection of a new Institute building, workshops, residencies, etc., at an estimated cost of close on a million pounds sterling. This great scheme was sanctioned by the Secretary of State, and the new Institute building was opened some seven years later by the Viceroy.

Once again war supervened; and once again India was faced with a closure of imports and the necessity of falling back on her own resources. For the second time the Forest Research Institute, now immensely stronger, has proved able to give invaluable services.

A recent publication, "Forest Research in India and Burma, 1941-42. Part I. The Forest Research Institute" (Dehra Dun : Forest Research Institute, 1943. Pp. iv +151. 1s. 11d.), summarizes some of the work carried out. "Even more than last year," says the writer, "the work of the Institute has been dictated by War, in fact in certain sections and branches practically all work on ordinary programmes has been suspended to deal with war research. Whilst the branches dealing with Sylviculture, Botany, Mycology, Chemistry and Entomology have only dealt, in most cases, more or less indirectly with war problems, though their assistance has been solicited on occasion, the brunt of the work has fallen, as was the case during the last War, on the Utilization Branch, which throughout has had to devote its whole time to war work."
During the year this branch has been continuously evolving substitutes for which there was a shortage for one reason or another as a result of the War. In conjunction with the Mechanical Section, the Wood Working Section has devoted its energies entirely to the demands of India and the Army. Containers of many types down to the ordinary pail, and for a variety of purposes, were constructed of plywood, on the basis of researches at the Institute, and were afterwards manufactured at factories. The Wood Technology Section spent the year identifying timbers mostly for the Army, but was also concerned with the selection of the right type of timber for aircraft. It also trained in timber identification sixty men of the Ordnance and Military Engineers Services Depart. ments. Ammunition boxes, walnut wood for rifles and other researche; were undertaken by the Timber Testing Section; while the Seasoning Section advised on the installation of kilns in various parts of India and also developed a simple hot-air kiln for quickly completing the seasoning of partially air-dried halfwroughts for such material as tool helves, shuttles, bobbins, picker-arms, etc. Unseasoned wood is useless for many of these purposes. The Adhesives for Plywood investigations have been already alluded to (Nature, Jan. $2 y$, p. 144). The Paper Pulp Section continued to work throughout the year, guided to a large extent by the Advisory Committee of the Indian Paper Makers' Association, there being a general shortage of paper in the country.

Some interesting research in the Chemistry Branch, carried out owing to war shortage, included a simplified method of preparing ephedrine and its salts from Indian Ephedras. This has been started on a factory scale, so that ephedrine salts are now being produced to replace the imported article. Retorts have been installed, as a result of experimental work, for the large-scale distillation of chir (Pinus longifolia) tar; the perfected process in these retorts will now yield products not only suitable for use in rope and rubber works but also for medicinal purposes. Tamarind seeds were shown to be a cheap source of pectin. A large amount of work was also carried out on charcoal for producer gas.

Truly has the great value and usefulness of her forests to India in times of stress, as in those of peace, justified the foresight of that Secretary of State in the distant days of 1862 .

\section{FORTHCOMING EVENTS}

(Meetings marked with an asterisk * are open to the public.)

Saturday, February 12

SHEFField METALLURGICAL Associatron (at 198 West Street, Sheffield), at 2.30 p.m.-Dr. G. Jessop:" "Some Electro-chemical Methods of Analysis".

Monday, February 14

FARMers' Chub (at the Royal Empire Society, Craven Street, London, W.C.2), at 2.30 p.m.-Mr. A. P. McDougall : "Increasing the Cattle Population". ILLUMrNaTrNa ENGINEERING Socretr (at the Royal Institution,
Albemarle Street, London, W.1), at 5 p.m.-Dr. H. Buckley: "Some Albemarle Street, London, W.1), at 5 p.m. -Dr. H. Buckley: "Some
18th Century Contributions to Photometry and Illuminating E..gineering".

Royal Grographicat Societr (at Kensington Gore, London, S.W.7), at 5 p.m.-Major R. C. Farrow: "Surveys for Power in the Coast Range of British Columbia"

Socrotr of Enarnegrs (at the Geological Society, Burlington House, Piccadilly, London, W.1), at 5 p.m.-Mr. Frank Parfett : Presidential Address.

Assocution of AUSTRIan Enginfers, Chemists aNd SoImNTimo

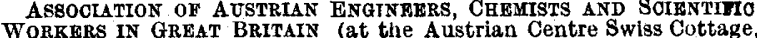
Workgrs IN GREat BRITAIN (at the Austrian Centre Swiss Cottage,
69 Eton Avenue, Hampstead, Iondon, N.W.3), at 7.15 p.m.-Dr. 69 Eton Avenue, Hampstead, London, N.W.3), 